\title{
Influence of roasting conditions on physicochemical and fatty acid profile of raw and roasted cashew kernel (Anacardium occidentale) grown in Nigeria
}

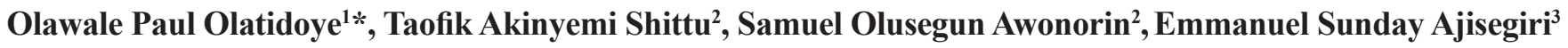 \\ ${ }^{1}$ Department of Food Technology, Yaba College of Technology, P.M.B 2011, Yaba, Lagos state, Nigeria \\ ${ }^{2}$ Department of Food Science and Technology, Federal University of Agriculture, Abeokuta, Ogun state, Nigeria \\ ${ }^{3}$ Department of Agricultural Engineering, Federal University of Agriculture, Abeokuta, Ogun state, Nigeria \\ *Corresponding author: waleolatidoye@gmail.com
}

\begin{abstract}
This study aimed at evaluating the effect of roasting conditions on some physicochemical and nutritional properties of cashew nut lipid fractions at different temperature $\left(100-160^{\circ} \mathrm{C}\right)$ and time $(20-60 \mathrm{~min})$. Raw and roasted cashew nuts were also analyzed for their composition in fatty acid by GC-FID. Physicochemical properties of the oil showed that the oil yield of roasted cashew nut oil (56.67-31.67\%) was significantly higher compared to unroasted oil (47.43\%). Also, cashew nut oil with mean values revealed that acid (12-0.86 $\mathrm{mg} \mathrm{KOH/g}$ of oil); saponification value (138.10-169.06 $\mathrm{mgKOH} / \mathrm{g}$ of oil), iodine value (55.50-36.19 $\mathrm{mg}$ of I/100g of oil); TBA(0.012-0.18mg); p-anisidine value (0.55-0.66); peroxide value (7.26-3.05 meq/ $\mathrm{kg}$ ) and free fatty acid (1.07-1.50\% oleic acid) which indicated that cashew nut oil is edible, non-drying and may not be suitable for soap making. Results of GC-FID analysis of the ethyl esters of saturated and unsaturated fatty acid of raw and roasted cashew nut showed that unsaturated fatty acids represented $60.57 \%$ for unroasted samples with roasted samples (79.67-83.67\%) while saturated fatty acids recorded (16.11-37.65\%). The fatty acid composition of the oils shows the presence of four main fatty acids: palmitic (9.25-29.50\%); stearic (4.4-9.34\%); oleic (34.75-65.60\%); and linoleic (1.35-20.66\%) with high oleic to linoleic ratio associated with high oil stability. The order of increase is oleic $>$ linoleic $>$ palmitic $>$ stearic in all the samples irrespective of roasting conditions. The result showed that minor changes occur in the fatty acids composition as the roasting temperature and time increased. It was concluded that the heat treatment used does not significantly affect the fatty acid profile content of cashew nuts preserving its antioxidant activity along with other bioactive compounds contained therein.
\end{abstract}

Keywords: Roasting, cashew nut, fatty acids, physicochemical properties, oleic, linoleic acid

\section{Introduction}

Edible nuts are cultivated and grown in a variety of growing conditions and climates, and are valued for their sensory, nutritional, and health attributes. Typically, edible nuts are rich sources of lipids and proteins; also contain certain vitamins and minerals in appreciable amounts. Consumption of nuts has become a very common phenomenon all over the world which has increased over the last decades due to their availability, affordable price, and the rise in the nutritional health awareness (Venkatachalam and Sathe, 2006). The consumption of edible nuts has been reported to have beneficial effects on human health due to their desirable lipid profile, which is higher in unsaturated fatty acids (USFA) than saturated fatty acids (SFA), and high antioxidants contents (Venkatachalam and Sathe, 2006). Several epidemiological studies have shown that frequent consumption of nuts can enhance cardiovascular health by decreasing serum levels of low-density lipoprotein- (LDL)cholesterol and risk of developing type II diabetes (Abou-Gharbia et al., 2000; Venkatachalam and Sathe, 2006). Also, nuts have also been shown to promote weight maintenance when consumed as the source of fat in moderate diets (Liaotrakoon et al., 2016). This is a healthier practice instead of eating high fat content snacks from unhealthy sources such high energy condense food items (fried food, confectionary snacks) which are known to contain saturated fatty acids (SFAs) and trans-fatty acids (Liaotrakoon et al., 2016; Venkatachalam and Sathe, 2006). Oxidation of fat and fat-containing foods is responsible for the deterioration in the food quality and nutritive value. Additionally, the oxidation of poly-unsaturated fatty acid(PUFA) in food may be related to diseases such as atherosclerosis, diabetes, and cancer (Abayomi and Ayodele, 2002; Adegoke et al., 2004; Liaotrakoon et al., 2016). The cashew plant (Anacardium occidentale) is one of the important tropical crops called "poor man's crop, rich man's food" (Atul Mohod et al., 2010). The name cashew is derived from ACAJU, a Portuguese word.
The cashew nut is native of central and South America with its main center of variation in Eastern Brazil from where Portuguese travelers took the cashew tree to colonies in India. Indian is the biggest producer and exporter in the world with a production rate of 0.53 million tons per year which is $49.5 \%$ of the total world production. India processed about 1.18 million tons of raw cashew seeds through 3650 cashew processing industries scattered in many states of country provided employment to over 0.5 million people (Anonymous, 2008). Nigeria is the leading producer of cashew in Africa and second world producer of cashew, producing $40.7 \%$ of total world production (ITDG, 2000; Opeke, 2005). Cashew was introduced into Nigeria in $17^{\text {th }}$ century, but large scale planting started in 1953 (Akinwale and Esan, 1989). However, cashew cultivation has spread to Western, Eastern and Northern states of Nigeria (Ayodele et al., 2001). Cashew tree was reported to flourish in all agro-ecological regions of Nigeria (Annonymous, 2008). Apart from being a source of useful products and byproducts for food, medicinal and industrial applications, cashew tress also give useful shade. Local consumption of processed cashew nuts and its demand by importing countries keep increasing, thereby providing opportunities for expansion of the cashew industry (O'Farrell et al., 2006). Cashew nut surplus of Nigeria is more than 50,000 tons per year which has a significant negative impact on Nigeria economy. Cashew nut is widely consumed as roasted, fried, salted or sugared snacks, as material for confectionery, bakery products and as a food ingredient (Azam-Alli and Judge, 2001), especially because it contains vital minerals which are seldom found in daily diets (Holland et al., 1991; CEPC, 1992; Davis, 1999). During the last two decades, cashew nut production in Nigeria has increased from 25,000 tonnes in 1980 to over 200,000 tonnes in 2005 . The primary product of cashew nuts is the kernel, which is the edible portion of the nut and is consumed either directly by the consumer; as roasted and 
salted nuts; in confectionery or as bakery products, as finely chopped kernels which is used in the production of sweets, ice creams, cakes and chocolates, both at home and industrially, and as paste to spread on bread. Also cashew kernels are consumed as an appetizer to cocktail drinks (Azam-Alli and Judge, 2001). It is estimated that $60 \%$ of cashew kernels are consumed in the form of snacks while the remaining $40 \%$ are included in confectionery, breakfast cereal, health food, salads and baked goods (Nagabhusana and Ravindranath, 1995; Akinwale, 1996a; ITDG, 2005). The effects of heat treatment on the behavior of some agricultural materials during handling and processing have been studied by other researchers (Elmastry et al., 2006; Irtwange, 2006; Akinoso et al., 2006). Commercial cashew nut processing is done by drum roasting, oil bath roasting and steam roasting which result in cashew kernel, testa and cashew shell liquid. Processing of raw cashew nuts into kernel involve heat treatment of the nuts, shelling, peeling, grading and packaging; however, shelling has presented the greatest processing problem. This is due to the peculiar kidney-shape configuration of the nut, the presence of a tough, leathery outer shell and the corrosive cashew nut shell liquid it contains (Ohler, 1979; Jain and Sivala, 1997). Though several works have been done on cashew nut shelling and a number of appropriate technologies have been developed (Ajav, 1996; Thivavarvongs et al., 1995a), the quality of yield in terms of percentage whole kernel still remains a major challenge. Roasting is one of the most important processes which provides important product attributes. One of the several objectives of nut roasting is to alter and significantly enhance the flavor, texture, color and appearance of the product. Roasting gives nuts a variety of textures and color, increasing their crispness and making them crunchier (Demir and Cronin, 2004; Ozdemir et al., 2001; Saklar et al., 2003). As a result of roasting, moisture level in nuts decreases from the initial value in the range $4-6 \%$ down to $1-3 \%$. Moisture reduction helps to create a desirable crisp texture. Roasting improves the flavor of raw nutmeats from its green taste. The conditions of roasting generally used by processors are $100^{\circ} \mathrm{C}-150^{\circ} \mathrm{C}$ with a residence time of $10-60 \mathrm{~min}$ (Ajav, 1996). Most of the cashew nut ( $>70 \%)$ were exported in shell until late 1990s after establishment of new cracking industries. In order to increase export of processed cashew nut and extend its market in the world, improvement of quality of processed cashew nut is necessary. The final quality of roasted cashew nut is influenced by the design of the roaster and time-temperature profile used. Heat transfer during roasting involves conduction, convection and radiation but convection by far is the most important mode of heat transfer that determines the rate and uniformity of roasting (Beggenstoss et al., 2008). Roasting is the most important steps in cashew nut processing, improvement of roasting process shall contribute to improvement of processed cashew nut products. The use of inappropriate temperature and time combination lead to quality defects such as short shelf life, discoloration, rancidity and poor flavor. Therefore, determination of roasting conditions (temperature-time combinations) more precisely and adhering to best conditions for roasting would ensure the production of good quality cashew nut. Currently, integrated studies are lacking on elucidating the effects of roast degree of cashew nut under different time-temperature condition on the physical and chemical properties of cashew nut. Temperature and time of roasting are two of the main factors that affect industrial roasting processes; they affect drying, heat transfer rate and physico-chemical changes in protein, carbohydrate and also kernel oil stability, which have not been documented. Since roasting affect product quality, control of the roasting process is significant because producers of cashew considered that determination optimum conditions for roasting cashew was a major problem. Yet this information is necessary for improvement and design of roasting process for maximizing nutrient retention. Therefore, it is necessary to understand these changes during roasting so as to obtain a better quality roasted cashew nut and also to determine changes in some chemical quality and to elucidate of the effect of time-temperature conditions on the physicochemical properties of the oil and fatty acid profile in cashew nut at different stages of roasting.

\section{Materials and Methods}

\section{Materials}

Freshly harvested and sun dried cashew nuts (Anacardium occidentale L.) were purchased at maturity from plantation of Cocoa Research Institute of Nigeria (CRIN), Idi-Ayunre, Ibadan, Nigeria. The dried raw cashew nuts were sorted and the diseased and immature nuts were discarded and spread on the floor until further processing is required.

\section{Cashew nut processing procedure}

Raw cashew nuts were steamed boiled using a steam boiler at a pressure of $0.62 \mathrm{Mpa}$ for $40 \mathrm{~min}$ contact time between steam and cashew nuts by the modified method of Kosoko et al., 2009. The steamed nuts were cooled for $24 \mathrm{~h}$ and shelled using a foot-pedaled shelling machine. It makes use of a pair of knife each shaped into the contour of half nut. When the knives come together by means of a foot operated lever, they cut through the shell around the nut, leaving the kernel untouched. The kernel is then removed from the shell using a small metal tool resembling pen knife to remove the kernel from the nuts. The kernels were then pre-dried in a cabinet drier (model LEEC F2, LEEC Ltd, Colwick, Nottingham), at a temperature of $60^{\circ} \mathrm{C}$ for $3 \mathrm{~h}$ to allow for the easy removal of the peels from the kernel. The peeled nuts were then packaged in glass bottles and stored at ambient condition $28 \pm 3^{\circ} \mathrm{C}$ and $78 \pm 2 \%$ (relative humidity).

\section{Roasting procedure}

Cashew nuts were roasted using a forced air pilot scale roaster at roasting air temperature of $100,120,140$, and $160{ }^{\circ} \mathrm{C}$ for $20-60 \mathrm{~min}$ which represents the range commonly used in nut industry. Prior to placing the sample in the roasting chamber, roaster was allowed to run for at least $2 \mathrm{~h}$ to obtain steady state condition. The kernel as a single layer was placed in the roasting chamber in small trays. Then every $5 \mathrm{~min}$ for a period of $1 \mathrm{~h}$, one tray was removed from the roasting chamber in less than 10 s so that steady state conditions were maintained during sampling. The trays were cooled to room temperature in desiccators and then stored in glass bottles for analysis.

\section{Chemical analysis}

\section{Determination of oil content}

The oil content was determined using the method described by AOAC (2005). The raw samples were ground in a blender. About $10 \mathrm{~g}$ of the ground sample was weighed on a chemical balance and wrapped up in a filter. It was then placed in the extraction thimble. Oil extraction unit was cleaned, dried in an oven and then cooled in the desiccator before weighing. Petroleum ether $(25 \mathrm{ml})$ was measured into the flask and the oil extracted with solvent. After extraction, the solvent was evaporated by drying in the oven. The flask and the content was then cooled in a desiccator and weighed. The oil content was calculated as follows:

$\%$ Oil content $=\frac{(X-Y)}{Z} X 100$

where:

$X=$ Weight of oil + flask

$Y=$ Weight of flask

$Z=$ Weight of Sample. 


\section{Determination of Acid value (free fatty acid FFA)}

A standard method of AOAC (2005) was used to determine the free fatty acid. About $25 \mathrm{ml}$ diethyl ether was mixed with $25 \mathrm{ml}$ alcohol and $1 \mathrm{ml}$ phenophalein solution and carefully neutralized with $0.1 \mathrm{M} \mathrm{NaOH}$. Approximately $5 \mathrm{~g}$ of fat was then dissolved in the mixed neutral solvent and titrated with aqueous $0.1 \mathrm{M} \mathrm{NaOH}$ and shaking constantly until the formation of pink color for $15 \mathrm{~min}$ was obtained. The amount of free fatty acid was calculated as a $\%$ of oleic acid using the formula given below.

$$
\text { Acid value }(\% \text { oleic acid })=\frac{\text { Titre }(\mathrm{ml}) \times 5.61}{\text { wt of sample used }}
$$

\section{Determination of Saponification value}

It is the number of $\mathrm{mg}$ of potassium hydroxide required to neutralize the fatty acid from complete hydrolysis of $1 \mathrm{~g}$ of fat. Standard method of AOAC (2005) was used for determination of saponification value. Approximately $2 \mathrm{~g}$ of fat was weighed into a conical flask and $25 \mathrm{ml}$ of alcoholic potassium hydroxide solution was added. The flask was heated in boiling water for $1 \mathrm{hr}$ with frequent shaking. About $1 \mathrm{ml}$ of phenolphthalein $1 \%$ solution was added and titrated alkali with $0.5 \mathrm{M}$ hydrochloric acid (a ml), carried out a blank titration at the time (b ml):

$$
\text { Saponification vaiue }=\frac{(b-a) * 28.05}{\text { weight of sample }}
$$

\section{Determination of Peroxide value (PV)}

Peroxide value measures the amount of iodine released when potassium iodide reacts with rancid fat. Standard method of AOAC (2005) was used for determination of PV. One gram $(1 \mathrm{~g})$ of fat and $1 \mathrm{~g}$ of potassium iodide was mixed with an acetic acid chloroform (2:1) solvent. After heating, $30 \mathrm{ml}$ of water was added and after $1 \mathrm{~min}$, the mixture was titrated with $0.01 \mathrm{~N}$ sodium thiosulfate until a blue color disappeared. The peroxide value was calculated using the formula given as:

$$
\text { Peroxide value }\left(\frac{m e q}{\mathrm{~kg}}\right)=\frac{((\mathrm{V}-B) x N f)}{W} 1000
$$

where:

$$
\begin{aligned}
& V=\text { Volume of sodiumthiosulfate consumed } \\
& B=\text { Volume of sodiumthiosulfate consumed during blank titration } \\
& W=\text { Weight of the sample, } g \\
& N_{f}=\text { Normality of sodiumthiosulfate } * \text { Factor }
\end{aligned}
$$

\section{Determination of iodine Value}

Iodine value measures the degree of unsaturation in oils. The value for fat or oil is defined as the weight of iodine absorbed by 100 parts by weight of the sample. The method of iodine value determination is Wijis' method. Wijis solution was prepared by dissolving $8 \mathrm{~g}$ of iodine trichloride in $200 \mathrm{ml}$ glacial acetic acid, dissolved $9 \mathrm{~g}$ of iodine in $300 \mathrm{ml}$ carbon tetrachloride. The solution was mixed and dilute to $1000 \mathrm{ml}$ with glacial acetic acid.

\section{Determination of p-Anisidine value}

Approximately $2.5 \mathrm{~g}$ of the oil was weighed into a $50 \mathrm{ml}$ volumetric flask. The sample was then dissolved and diluted to the mark with $\mathrm{n}$-hexane. The absorbance $\left(\mathrm{A}_{1}\right)$ of the solution at $350 \mathrm{~nm}$ in a $10 \mathrm{~mm}$ cell against a blank n-hexane was measured. About $5 \mathrm{ml}$ of the sample solution was then pipette into a $10 \mathrm{ml}$ stoppered test tube and exactly $1 \mathrm{ml}$ of $\mathrm{p}$-anisidine value solution $(2.5 \mathrm{~g} / \mathrm{L}$ in glacial acetic acid $)$ was added. After exactly $10 \mathrm{~min}$, the absorbance $\left(\mathrm{A}_{2}\right)$ as against the reagent blank was measured. The $\mathrm{p}$-anisidine value is calculated using the formula below as described by AOCS Method Cd8-80 (2003).

\section{$p-$ Anisidine value $=\frac{25(1.2 A s-A b)}{W}$}

where:

$A_{s}=$ absorbance of fat solution after reaction with the p-anisidine,

$A_{b}=$ absorbance of the fat solution, $W=$ weight of the sample

\section{Calculated oxidizability value (Cox)}

The oxidative stability of cashew kernel roasted at different temperature and time combination based on unsaturated fatty acids (USFAs) content was calculated by method of Fatemi and Hammond (1980).

$\operatorname{Cox}=\frac{\{1(18: 1 \%)+10.3(18.2 \%)+21.6(18.3 \%)\}}{100}$

\section{Oxidation value $(\mathrm{OV})$}

Oxidation value (OV) was calculated from Holm's equation as it is given as Oxidation value $(\mathrm{OV})=\mathrm{P}$. $\mathrm{Av}+2(\mathrm{PV})$

The theoretical flavour score $(\mathrm{F})$ was calculated from the equation

Theoretical flavour score $\mathrm{F}=7.7-0.35(\mathrm{OV})$ (List et al., 1974)

\section{Determination of Thiobarbituric acid value}

The thiobarbituric acid (TBA) value was measured according to the Official Method and Recommended Practices of the American Oil Chemists Society (AOCS, 2003). Approximately $10.0 \mathrm{~g}$ of the sample was macerated with $50 \mathrm{ml}$ of water for $2 \mathrm{~min}$ and then washed into a distillation flask with $47.5 \mathrm{ml}$ of water. About $2.5 \mathrm{ml}$ of $4 \mathrm{M}$ hydrogen chloride acid was added to bring the $\mathrm{pH}$ to 1.5 . The flask was heated on an electric mantle for $10 \mathrm{~min}$ to collect about $50 \mathrm{ml}$ distillate. About $5 \mathrm{ml}$ of the distillate was pipetted into a glass-stoppered and about $5 \mathrm{ml}$ of TBA reagent was stoppered, shaken and heated in boiling water for 35 min. A blank was prepared and the absorbance was measured against the blank at $538 \mathrm{~nm}$ by using a spectrophometer (Bionave, WPA S2100, UK) to give the TBA values.

\section{Determination of fatty acid composition}

The fatty acid methyl esters of total lipids were obtained by direct transmethylation according to a standard method of AOAC (2005). Approximately $0.1-0.2 \mathrm{~g}$ oil from the sample were mixed with $5 \mathrm{ml} 0.5$ $\mathrm{N}$ methanolic $\mathrm{NaOH}$ and boiled until the droplets of the fat disappears for $10 \mathrm{~min}$ using a condenser in order to allow saponification. Then 5 $\mathrm{ml}$ of $\mathrm{BF}_{3}$ were added to the flask from the pulp or automatic pipette through the top of the condenser, and boiled for $1 \mathrm{~min}$. Then $5 \mathrm{ml}$ of the heptane was added from the top of the condenser and left to cool. The solution was transferred into the $25 \mathrm{ml}$ flask, and saturated $\mathrm{NaCl}$ solution 
was added to the flask and shaken gently, saturated $\mathrm{NaCl}$ solution was added until the solution in the flask was $25 \mathrm{ml}$. About $1 \mathrm{ml}$ of solution from upper layer was transferred into a bottle after phene separation. The bottle was placed in deep freezer until the analysis. Fatty acid methyl esters were analyzed using gas chromatography (HP 6890 Powered with HP chemstation Rev. A09.01 [1206] software with a flame ionization detector. The carrier gas was hydrogen at a flow rate of $1.0 \mathrm{ml} / \mathrm{min}$. A capillary column, HP5MS (30 m x $0.25 \mathrm{~mm}$ x $0.25 \mu \mathrm{m})$ was used for the fatty acid analysis. Injector temperature used was split injector, detector temperature and column temperatures were 320 and $150{ }^{\circ} \mathrm{C}$, respectively. Injection quantity was $1 \mu \mathrm{l}$. The oven was programmed at initial temperature of $50{ }^{\circ} \mathrm{C}$; first ramped was curved out at $5{ }^{\circ} \mathrm{C} / \mathrm{min}$ to $150{ }^{\circ} \mathrm{C}$ and $2^{\text {nd }}$ ramped at $10^{\circ} \mathrm{C} / \mathrm{min}$ to 250 ${ }^{\circ} \mathrm{C}$. Hydrogen pressure used was $22 \mathrm{psi}$ and compressed air was set at $28 \mathrm{psi}$. The fatty acids methyl esters were identified by comparing their retention times to those of a standard mixture of fatty acids and the peak areas were integrated. The surface area of the peaks which was assimilated to triangles gave the fatty acid composition of the mixture injected (\% in weight of methyl ester mixture) according to the formula:

\section{$X \%$ of methyl ester $=\frac{\text { Surface area of corresponding peak }}{\text { Surface area of total peak }} \times 100$}

\section{Statistical analysis}

Data collected from all experiments were in triplicates and data expressed as means \pm standard deviations. The data were subjected to one-way analysis of variance (ANOVA) and differences between treatment means were separated using Duncan's Multiple Range Test (DMRT) out to assess significant differences between means $(p<0.05)$. All statistical procedures were carried out according to methods of Steel and Torrie (1990), while computation was done using SAS software package.

\section{Results and discussion}

\section{Changes in physicochemical properties of cashew nut oil during roasting}

Roasting causes a net loss of matters in the forms of water vapor, volatile compounds, degradation of polysaccharides, sugars, amino acids and chlorogenic acids resulting in the formation of caramelization and condensation products with an increase in organic acids and lipids. The mean values for the physicochemical properties of raw and roasted cashew nut at different roasting condition were given in Table 1 . The result of the physicochemical properties of cashew nut oil show saponification value with mean values ranged from $169.02 \mathrm{mg} \mathrm{KOH} / \mathrm{g}$ of oil for the unroasted sample to (142.40-155.80 mg KOH/g of oil), (160.44-142.55 $\mathrm{mg} \mathrm{KOH} / \mathrm{g}$ of oil), (145-162.00 mg KOH/g of oil) and (145-137.20 mg $\mathrm{KOH} / \mathrm{g}$ of oil) for cashew nut roasted at $100^{\circ} \mathrm{C}, 120^{\circ} \mathrm{C}, 140^{\circ} \mathrm{C}$ and $160^{\circ} \mathrm{C}$ respectively. Peroxide value has $3.08 \mathrm{meq} / \mathrm{kg}$ for control while $(5.20-6.80$ $\mathrm{meq} / \mathrm{kg}),(6.12-6.91 \mathrm{meq} / \mathrm{kg}),(6.80-8.10 \mathrm{meq} / \mathrm{kg}),(5.80-7.20 \mathrm{meq} / \mathrm{kg})$ for cashew nut roasted at $100^{\circ} \mathrm{C}, 120^{\circ} \mathrm{C}, 140^{\circ} \mathrm{C}$, and $160^{\circ} \mathrm{C}$ respectively. Iodine value for control is $45.12 \mathrm{mg}$ of $\mathrm{I} / 100 \mathrm{~g}$ of oil, while $37.00-50.2$ $\mathrm{mg}$ of I/100g of oil, $40.11-46.27 \mathrm{mg}$ of $\mathrm{I} / 100 \mathrm{~g}$ of oil; $36.80-43.10 \mathrm{mg}$ of $\mathrm{I} / 100 \mathrm{~g}$ of oil; $43.00-55.40 \mathrm{mg}$ of $\mathrm{I} / 100 \mathrm{~g}$ of oil were mean values obtained for cashew nut roasted at $100^{\circ} \mathrm{C}, 120^{\circ} \mathrm{C}, 140^{\circ} \mathrm{C}$, and $160^{\circ} \mathrm{C}$ respectively. Peroxide value for control is $0.83 \mathrm{meq} / \mathrm{kg}$ while $10.20-11.50 \mathrm{meq} / \mathrm{kg}$; $10.84-11.99 \mathrm{meq} / \mathrm{kg} ; 10.59-11.90 \mathrm{meq} / \mathrm{kg} ; 9.60-10.80 \mathrm{meq} / \mathrm{kg}$, were mean values obtained for cashew nut roasted at $100^{\circ} \mathrm{C}, 120^{\circ} \mathrm{C}, 140^{\circ} \mathrm{C}$, and $160^{\circ} \mathrm{C}$ respectively. TBA for control is 0.18 while $0.016-0.0012 ; 0.016-$ 0.012 ; $0.016-0.0012,0.014-0.0010$ were mean values obtained at $100^{\circ} \mathrm{C}$, $120^{\circ} \mathrm{C}, 140^{\circ} \mathrm{C}$, and $160^{\circ} \mathrm{C}$ respectively. Free fatty acid (FFA) for control is 1.62 while $1.60-1.55 ; 1.58-1.53 ; 1.60-1.51 ; 1.55-1.50$ were values at $100^{\circ} \mathrm{C}, 120^{\circ} \mathrm{C}, 140^{\circ} \mathrm{C}$, and $160^{\circ} \mathrm{C}$ respectively. The bulk chemical properties such as acid value (AV), saponification value (SV), peroxide value $(\mathrm{PV}), \mathrm{p}$-anisidine value ( $\mathrm{p}-\mathrm{AV})$, give structural stability and quality information about oils and fats (Mabaleha and Yeboah, 2004). The oil has a golden colour and nutty taste and remained uniformly liquid at room and refrigeration temperature. The acid value ranged from 0.86 to $12.00 \mathrm{mgKOH} / \mathrm{g}$ of oil (Table 1). The acid value increased as roasting temperature and time increased. The acid value measures the amount of these free fatty acids on oils which can be used as a measure of its quality with respect to rancidity and oxidation. The acid value is usually twice as large as the free fatty acid (FFA) and this was the case in this work. The high acid value for the nuts was due thermal processing involved in the roasting process and is an indication that the triacylglycerol present in the oil has been hydrolyzed to lipase. Lower acid value renders the process of refining a bit easier. Normally, fatty acids are in the triglyceride form, however, during processing the fatty acid my get hydrolyzed into free fatty acid.

The higher the acid value found, the higher the level of free fatty acids which translates into decreased oil quality. Acceptable levels for oil samples should be below $0.6 \mathrm{mgKOH} / \mathrm{g}$ of oil (AOCS, 2003). The maximum acid value of edible oil is $15 \mathrm{mgKOH} / \mathrm{g}$ of oil (Krishnamurthy, 1982). Champe and Harvey (1994) reported that acid value is a measure of the amount of free fatty acids and the extent to which the glycerides in the oil have been decompose by lipase action. The low value recorded suggest good post harvest handling of raw materials used and low level of moisture content in the oil samples. Coenen (1976) reported that abuse of raw materials can increase the rate of hydrolysis and therefore lead to high \% FFA above 5\%. Most of the acid values for this cashew nut oil were below this level, hence these oils can be considered as good edible oils. According to overall analysis of variance (ANOVA), acid values significantly varied among all the roasted samples. Sample roasted at $120^{\circ} \mathrm{C}$ for $60 \mathrm{~min}$ have significantly higher acid value than the rest of oil samples (Table 1). This hydrolysis is probably caused by a variety of agents presence of moisture in the oil, elevated temperature (above room temperature) and most important of all, lipase (enzyme) coming from the source or contaminating microorganism. This observation supports previous study that unrefined vegetable oil had higher acid value than refined oils (Rajiko et al., 2010). In addition, high acid values which result from high amounts of free fatty acid in oil may be due to the method of processing of the nuts. The nuts are often sun dried for days, to reduce the moisture content and then stored. This may favour the action of lipolytic enzymes which hydrolyze triglycerides in the nuts, liberating free fatty acids. Also the nuts undergo steaming or boiling and spread on the floor before the nuts are extracted, this may also induce slow fermentation as the nuts are damp. Hence, the conditions, duration of storage and drying of the nuts and the extraction of the oils, can increase the acid value (Djeumako et al., 2000). It has also been shown that acid value increases with temperature as in the extraction of Shea butter with acid value of (4-10.01 $\mathrm{mgKOH} / \mathrm{g}$ of oil) (Kapchie et al., 2000) and Ricinodendron heudeloti oil (2-9.24 mgKOH/g of oil) (Aboubakar et al., 2000). Oils usually contain small amount of free fatty 
acids such as that when exposed to the air, these fatty acids which are responsible for the acidity and oxidability of oil, produce unpleasant odour. In refined vegetable oils, the lower the free fatty acid content the more stable the oil, the more acceptable the oil to the human palate (Codex Alimentarius, 1999). High acid values which result from high amount of free fatty acid in oil may be due to the roasting method and roasting conditions used for the nut. Saponification value of raw and roasted cashew nut ranged from $169.06 \mathrm{mgKOH} / \mathrm{g}$ of oil to 138.10 $\mathrm{mgKOH} / \mathrm{g}$ of oil. Samples roasted at high temperature and time had the lowest saponification value. The saponification value decreased as roasting temperature and time increased. There was significant difference between the mean saponification values of all the samples at $\mathrm{p}<0.05$. However, the saponification values were lower than those of Cucumis melon (melon seed, $193 \mathrm{mg} \mathrm{KOH} / \mathrm{g}$ of oil), corn oil,187-195 mg KOH/g of oil), (cotton seed oil, 189-198 mg KOH/g of oil), (peanut oil, 189-194 $\mathrm{mgKOH} / \mathrm{g}$ of oil), (soy bean oil, 189-194 $\mathrm{mgKOH} / \mathrm{g}$ of oil), (palm oil, 190-209 mgKOH/g of oil), sesame oil, 189-195 mgKOH/g of oil) and (olive oil,190- $192 \mathrm{mgKOH} / \mathrm{g}$ of oil) (Codex Alimentarius, 1999). They were also lower than those of oil rich in saturated fatty acids (SFA) such as Cocos nucifera, coconut (248-265), Elais guineensis, palm kernel oil (230-254 $\mathrm{mgKOH} / \mathrm{g}$ of oil) (Codex Alimentarius, 1999). These values of saponification values indicate the absence of lauric acid in the cashew nut oil but the presence of medium chain-length fatty acids. Saponification value indicates the average molecular complexity of the molecule (Hilditch, 1947) and also, it is inversely proportional to mean molecular weight of the glycerides in the oil. It depends on the neutralization of the free fatty acids in oil and complete saponification of the fatty material (Moreau et al., 1999).

Table 1. Analysis of physicochemical properties of cashew nut roasted at different roasting conditions

\begin{tabular}{|c|c|c|c|c|c|c|c|c|}
\hline $\begin{array}{l}\text { Temp. } \\
\left({ }^{\circ} \mathrm{C}\right)\end{array}$ & $\begin{array}{l}\text { Time } \\
(\min )\end{array}$ & $\begin{array}{c}\mathrm{SV} \\
\text { (mg KOH/ } \\
\text { g of oil) }\end{array}$ & $\begin{array}{c}\text { PV } \\
(\mathrm{meq} / \mathrm{kg})\end{array}$ & $\begin{array}{c}\text { IV } \\
\text { (mg of I/ } \\
100 \mathrm{~g} \text { of oil) }\end{array}$ & $\begin{array}{c}\mathrm{AV} \\
\text { (mg KOH/ } \\
\text { g of oil) }\end{array}$ & $\begin{array}{l}\text { TBA } \\
(\mathrm{mg})\end{array}$ & $\begin{array}{c}\text { FFA } \\
(\% \text { oleic acid })\end{array}$ & $\begin{array}{l}\text { p-anisidine } \\
\text { value }\end{array}$ \\
\hline Control & & $169.06 \pm 0.05 \mathrm{~g}$ & $3.05 \pm 0.04 \mathrm{a}$ & $45.16 \pm 0.05 \mathrm{e}$ & $0.86 \pm 0.04 \mathrm{a}$ & $0.18 \pm 0.00 \mathrm{a}$ & $1.67 \pm 0.08 \mathrm{~d}$ & $0.55 \pm 0.04 \mathrm{a}$ \\
\hline 100 & $\begin{array}{l}20 \\
40 \\
60\end{array}$ & $\begin{array}{c}160.50 \pm 6.65 \mathrm{f} \\
148.65 \pm 0.64 \mathrm{~d} \\
140.65 \pm 0.35 \mathrm{ab}\end{array}$ & $\begin{array}{l}5.45 \pm 0.35 \mathrm{~b} \\
6.20 \pm 0.4 \mathrm{~cd} \\
6.79 \pm 0.02 \mathrm{ef}\end{array}$ & $\begin{array}{l}38.00 \pm 1.41 \mathrm{~b} \\
43.31 \pm 0.30 \mathrm{~d} \\
50.29 \pm 0.12 \mathrm{~g}\end{array}$ & $\begin{array}{l}10.50 \pm 0.42 \mathrm{~d} \\
11.22 \pm 0.31 \mathrm{gf} \\
11.55 \pm 0.06 \mathrm{fg}\end{array}$ & $\begin{array}{c}0.017 \pm 0.00 \mathrm{c} \\
0.014 \pm 0.00 \mathrm{bc} \\
0.012 \pm 0.00 \mathrm{~b}\end{array}$ & $\begin{array}{c}1.62 \pm 0.05 \mathrm{bcd} \\
1.57 \pm 0.04 \mathrm{abc} \\
1.56 \pm 0.05 \mathrm{abc}\end{array}$ & $\begin{array}{c}0.56 \pm 0.02 \mathrm{~b} \\
0.58 \pm 0.01 \mathrm{c} \\
0.60 \pm 0.04\end{array}$ \\
\hline 120 & $\begin{array}{l}20 \\
40 \\
60\end{array}$ & $\begin{array}{c}160.71 \pm 0.38 \mathrm{f} \\
155.60 \pm 0.55 \mathrm{e} \\
142.72 \pm 0.23 \mathrm{bc}\end{array}$ & $\begin{array}{c}6.13 \pm 0.01 \mathrm{~cd} \\
6.46 \pm 0.03 \mathrm{de} \\
6.95 \pm 0.06 \mathrm{f}\end{array}$ & $\begin{array}{c}40.17 \pm 0.08 \mathrm{c} \\
44.18 \pm 0.04 \mathrm{de} \\
46.53 \pm 0.50 \mathrm{f}\end{array}$ & $\begin{array}{c}10.92 \pm 0.11 \mathrm{~cd} \\
11.07 \pm 0.03 \mathrm{de} \\
12.00 \pm 0.14 \mathrm{f}\end{array}$ & $\begin{array}{c}0.016 \pm 0.00 \mathrm{c} \\
0.014 \pm 0.00 \mathrm{bc} \\
0.012 \pm 0.00 \mathrm{~b}\end{array}$ & $\begin{array}{c}1.59 \pm 0.01 \mathrm{bcd} \\
1.56 \pm 0.01 \mathrm{abc} \\
1.53 \pm 0.01 \mathrm{ab}\end{array}$ & $\begin{array}{c}0.57 \pm 0.02 \mathrm{ab} \\
0.59 \pm 0.04 \mathrm{~d} \\
0.62 \pm 0.02\end{array}$ \\
\hline 140 & $\begin{array}{l}20 \\
40 \\
60\end{array}$ & $\begin{array}{c}162.50 \pm 0.71 \mathrm{f} \\
154.43 \pm 0.33 \mathrm{e} \\
145.64 \pm 0.34 \mathrm{~cd}\end{array}$ & $\begin{array}{l}6.85 \pm 0.06 \mathrm{ef} \\
7.26 \pm 0.05 \mathrm{~g} \\
8.45 \pm 0.50 \mathrm{~h}\end{array}$ & $\begin{array}{l}36.19 \pm 0.87 \mathrm{a} \\
41.06 \pm 1.35 \mathrm{c} \\
43.27 \pm 0.24 \mathrm{~d}\end{array}$ & $\begin{array}{c}10.55 \pm 0.06 \mathrm{~d} \\
11.02 \pm 0.03 \mathrm{ef} \\
11.85 \pm 0.08 \mathrm{gh}\end{array}$ & $\begin{array}{c}0.016 \pm 0.00 \mathrm{c} \\
0.015 \pm 0.00 \mathrm{bc} \\
0.012 \pm 0.00 \mathrm{~b}\end{array}$ & $\begin{array}{l}1.62 \pm 0.03 \mathrm{~cd} \\
1.56 \pm 0.04 \mathrm{abc} \\
1.52 \pm 0.02 \mathrm{ab}\end{array}$ & $\begin{array}{c}0.58 \pm 0.04 \mathrm{c} \\
0.61 \pm 0.03 \\
0.63 \pm 0.02\end{array}$ \\
\hline 160 & $\begin{array}{l}20 \\
40 \\
60\end{array}$ & $\begin{array}{c}145.64 \pm 0.19 \mathrm{~cd} \\
141.95 \pm 0.07 \mathrm{abc} \\
138.10 \pm 1.27 \mathrm{a}\end{array}$ & $\begin{array}{c}5.82 \pm 0.3 \mathrm{bc} \\
6.53 \pm 0.4 \mathrm{de} \\
7.22 \pm 0.3 \mathrm{~g}\end{array}$ & $\begin{array}{c}43.06 \pm 0.64 \mathrm{~d} \\
51.45 \pm 0.07 \mathrm{~g} \\
55.50 \pm 0.13\end{array}$ & $\begin{array}{c}9.65 \pm 0.06 \mathrm{~b} \\
10.05 \pm 0.06 \mathrm{c} \\
10.85 \pm 0.06 \mathrm{de}\end{array}$ & $\begin{array}{c}0.014 \pm 0.00 \mathrm{bc} \\
0.012 \pm 0.00 \mathrm{a} \\
0.012 \pm 0.04 \mathrm{a}\end{array}$ & $\begin{array}{l}1.53 \pm 0.03 \mathrm{abc} \\
1.56 \pm 0.05 \mathrm{abc} \\
1.50 \pm 0.01 \mathrm{a}\end{array}$ & $\begin{array}{l}0.60 \pm 0.05 \mathrm{e} \\
0.64 \pm 0.12 \mathrm{f} \\
0.66 \pm 0.22 \mathrm{~g}\end{array}$ \\
\hline
\end{tabular}

Values in the same column with different lower-case letters(a-g) are significantly different at $p<0.05$

Saponification is an indication of the molecular weight of triglycerides in oil. Higher saponification value indicates high proportion of lower fatty acid since saponification in inversely proportional to the average molecular weight or chain length of the fatty acids (Mohammed et al., 2001). The shorter the average chain length $\left(\mathrm{C}_{4}-\mathrm{C}_{12}\right)$ the higher is the saponification value (Tamzid et al., 2007). Generally, fats and oils with high proportion of shorter carbon chain lengths of the fatty acids have high saponification values (Kirk and Sawyer, 1991). Low molecular weight fatty acids have more glycerides per gram of fat than high molecular weight acids and hence greater saponification value. Peroxide values cashew roasted at different temperature and time combination ranged from 3.05 to $8.45 \mathrm{meq} / \mathrm{kg}$ of oil. Also the peroxide increased as the temperature and time of roasting increased. The highest peroxide value $\left(8.45 \mathrm{meq} / \mathrm{kg}\right.$ of oil) was obtained at $140^{\circ} \mathrm{C}$ for $60 \mathrm{~min}$ (Table 1$)$. Peroxide value is an indication of the amount of hydroperoxides present in the oil. These compounds arise from lipid oxidation. The lower the peroxide value, the better the quality of the oil. Hence, the peroxide value is a measure of oil quality (Codex Alimentarius, 1999). There was significant difference between the mean peroxide values of all the samples at $p<0.05$. The mean value of peroxide value is within the range of peroxide values $(<10)$ generally reported for fresh fat and oil (Kirk and Sawyer, 1991). A rancid taste is often noticed in many oils when the peroxide value is between 20 and $40 \mathrm{mEq} / \mathrm{kg}$ oil (Kirk and Sawyer, 1991). The values also fall within the standards $(\mathrm{PV}<10 \mathrm{mEq} / \mathrm{Kg}$ fat or oil) stated by Codex Alimentarius for edible oils. The low value of peroxide value of the cashew nut oil is a good indicator of the stability of the oil against oxidation and rancidity. Also, these nuts are often stored for long after harvest before processing, which may lead to a rise in its peroxide values. The peroxide value also depends on the method of preservation and storage of oil, the state of oxygenation (quantity of oxygen consumed), the method of oil extraction used and the type fatty acid present in the oil. The high peroxide value in some nuts oil may be due to much exposure of the nuts to the sun during drying, because lipid oxidation resulting from the absorption of oxygen which increases the formation of peroxides. Also, it can be due to heating of oil during roasting. Heat favours oxidation of fatty acids increasing the formation of peroxide (Cheftel and Cheftel, 1992). This oil contains mostly polyunsaturated fatty acid which could easily undergo oxidation, raising peroxide value in these oils. The results are in agreement with those reported by Seda et al., (2001) and Adegoke et al., (2004) who indicated that roasting process raised acid, peroxide and iodine values of peanut oil. Also, Ozdemir et al., (2001) observed that as degree of roasting increased, peroxide value of hazelnut gradually decreased while FFA increased. Higher peroxide value and lower FFA with increasing roasting degree was also observed in the study of Mostafa, (1987) for peanut, peroxide value in the sample was lower than the flavour quality end point of $8 \mathrm{meq} / \mathrm{kg}$ (Braddock et al., 1995). Iodine value of cashew nut ranged from $38.00-55.50 \mathrm{mg}$ of $\mathrm{I} / 100 \mathrm{~g}$ of oil. Iodine values also increased as the roasting temperature and time increased. There was significant difference between the mean iodine values of all the samples at $\mathrm{p}<0.05$ as shown by Analysis of Variance. The highest iodine value 
occurred at roasting temperature of $160^{\circ} \mathrm{C}$ and a roasting time of $60 \mathrm{~min}$. The iodine is a characteristic of the unsaturation of a fatty acid or its esters. Lipids with unsaturated fatty acid (containing one or more double bonds) are easily assimilated and broken down to produce calorific energy than saturated fatty acids. The degree of unsaturation of lipids can therefore be estimated by determining the iodine value, for these lipids quantitatively add iodine and the quantity of halogen absorbed represents a measure of the average unsaturation of the lipid. One molecule of iodine is bound to a double bond. The higher the iodine value, the higher the unsaturation in the oil. However, when the iodine value becomes too high, the stability of the oil reduces because it is more likely to undergo oxidation. The iodine values of cashew nut oil were similar to those of peanut oil (86-107 meq of I/g of oil), pressed crude oil of Allanblackia floribunda seeds (38.78 meq of I/g of oil), cocoa butter (32-42 meq of I/g of oil), coconut (6-10.6 meq of I/g of oil), palm oil (50-55 meq of I/g of oil), palm kernel oil (14-21 meq of I/g of oil) (Codex Alimentarius, 1999) and lower than C. sativus (115-118\%), cottonseed (100-123), sesame (104-120\%), sunflower (118-141\%), Glycine max, soybean oil (124$139 \%)$. This low iodine value in cashew nut is probably due to its low level of linolenic acid (0.13-0.38\%) (Codex Alimentarius, 1999). The iodine values were within the range of 50-55 specified by Codex Alimentarius (Codex Standard 210, 2003). The values were low indicating a low degree of unsaturation. Oils have been classified into three groups based on iodine value, oil is classified as non-drying if the peroxide value ids less than 100, as semi-drying if the peroxide value is between 100 and 130 , or as drying oil if the peroxide value is between 130-200 (Cocks and Rede,1996). The iodine values obtained for the cashew nut were below 100 indicating that the oil is non-drying. Thus, the oil will not be suitable for the production of industrial products such as paints, varnishes and surface coatings (Ellis et al., 2007). The free fatty acids (FFA) are an important parameter in evaluating the quality of fats and oil with respect to rancidity and oxidation. Free fatty acid of raw and roasted cashew nut ranged from 1.50 to $1.67 \%$ Oleic acid. There was significant difference between the mean free fatty acid values of all the samples at $p<0.05$. The low FFA values are an indication of the stability of the oil against oxidation and rancidity. The results obtained showed that the development of free fatty acid as an indicator of lipolytic rancidity in cashew nut fat due to roasting process. It could be observed that the FFA content increased slightly and gradually in all the samples after roasting process. The increase in FFA could be attributed to the hydrolysis of some triglycerides and phosphatides and the liberation of free fatty acids (June, 1981). This variation in increase could be explained by accelerating effect of roasting temperature in the hydrolysis of triglycerides. These results are in reasonable agreement with those reported by Alonso et al. (1977) and Iskander et al., 2010. Makeri et al., (2011) also reported similar results during of peanuts who reported that free fatty of peanut oils increased with the temperature and time treatments which could result from decomposition of the glycerides in the oil by heat treatment or from increased activities of lipase enzyme at the lower temperature and time treatment. The TBA values were taken as a measure for the degree of oxidation during the hot-air roasting of cashew nut. Effect of hot-air roasting time on TBA values of cashew nut showed that samples treated with $60 \mathrm{~min}$ had the highest TBA values without a significant $(\mathrm{P}<0.05)$ difference from other samples. TBA values were in the range of $0.02-0.03$ $\mathrm{mg} / \mathrm{kg}$. It can be noticed that roasting increased TBA value significantly. These results are in agreement with those reported by Chiou et al., (1991) and Abayomi et al., (2002) who indicated that there was a slight increase in TBA value of peanut oil after roasting. From the previous results, it can be stated that roasting had no significant effect on malonaldehyde amount of raw cashew nut oil, while roasting increased it. Gou et al., (2000) studied physicochemical and sensory property changes in almond found that TBA values increased after an intensive roasting process (12 min at $220^{\circ} \mathrm{C}$ or after $14 \mathrm{~min}$ at $200^{\circ} \mathrm{C}$ ). This could be due to the production during the maillard reaction of antioxidant products, which are absorbed in the oil (Sandmeier, 1996). This results support the report of Jittrepotih et al., 2010 who worked on the influence of microwave irradiation on lipid oxidation of peanut.

The p-anisidine and TBA values were lower; this indicates that lipid degradation was lowest at this temperature. The slight change in p-anisidine or totox value indicated a slight increase in both primary and secondary oxidation in the oil samples. This implies that cashew nut oil is fairly stable under ambient storage condition and its behaviour may be attributed to the presence of the natural antioxidant. The values were significantly $(p<0.05)$ lower than the maximum value $(p-A V=10)$ recommended for edible purposes. The totox values value were also within the range of Codex standards for edible oil. The high content of linoleic acid would increase the susceptibility of the oil to oxidation and hence high oxidation value (OV). High refractive index values are indications of the presence of considerable amount of PUFA in the oil. The OV (6.65-17.53) indicates that considerable oxidative activity might be due either lipoxygenase or autoxidation. The lipoxygenase activity of cashew nut oil has not been reported. The oxidative values are comparable with those reported for phaseolus vulgaris seed oil (11.031.2) (Attia et al., 1996) and chick pea (13.09-22.34) (Zia-UI-Haq et al., 2007). The relative lower oxidation value does not require the study of lipoxygenase activity of cashew nut oil. The theoretical flavour scores (F) of the oil from all roasted cashew nut samples were shown in Table 4. Although the equation was developed for soybean oil, the flavour scores (1.57-5.37) indicate that the oil from the cashew nut would receive a lower acceptance as an edible oil without further refining. The roasted samples differed significantly with respect to theoretical flavour scores. The values for the flavour scores are comparable to flavour values for phaseolus vulgaris seed oil (3.2-3.9) (Mahaleha and Yeboah, 2004) and chickpea (0.92-3.11) (Zia-UI-Haq et al., 2007).

\section{Changes in fatty acid composition of cashew nut during roasting}

Table 2 shows the fatty acid composition of raw and roasted cashew nut at different roasting conditions. The saturated fatty acid present were myristic (C14:0); palmitic (C16:0), stearic (C18:0), arachidic (C20:0) and behenic (C22:0); the monounsaturated acid were palmitoleic $(\mathrm{C} 16: 1)$, Oleic $(18: 1)$ while the polyunsaturated compound were linoleic (C18:2), linolenic(C18:3), arachidonic (C20:4), Erucic (C22:1), lignoceric (C24:1). Myristic content ranged between 0.04 to $1.5 \%$, palmitic ranged between 29.50 to $8.33 \%$; stearic (4.42 to $0.44 \%$ ), arachidic ( 0.22 to $2.04 \%)$, behenic $(0.52$ to $0.02 \%)$. Cashew nut roasted at $120^{\circ} \mathrm{C}$ for $40 \mathrm{~min}$ showed the highest content of $0.11 \%$, which is lower than the unroasted sample $(1.15 \%)$, cashew nut sample roasted at $100^{\circ} \mathrm{C}$ for $60 \mathrm{~min}$ has the lowest content of $0.03 \%$. Palmitic was highest when roasted at $100^{\circ} \mathrm{C}$ for $60 \mathrm{~min}(10.71 \%)$ followed by cashew roasted at $160^{\circ} \mathrm{C}$ for $60 \mathrm{~min}(10.59 \%)$. Stearic content was highest when roasted at $140^{\circ} \mathrm{C}$ for $60 \mathrm{~min}(4.42 \%)$, followed by $9.34 \%$ for samples roasted at $100{ }^{\circ} \mathrm{C}$ for $60 \mathrm{~min}$. Arachidic content ranged between 2.04 to $0.1 \%$ with the highest content at $0.45 \%$ and $0.1 \%$ which were roasted at $100^{\circ} \mathrm{C}$ for $20 \mathrm{~min}$ and $100^{\circ} \mathrm{C}$ for $40 \mathrm{~min}$ respectively. Behenic was highest in cashew nut roasted at $100^{\circ} \mathrm{C}$ for $20 \mathrm{~min}(0.05 \%)$ and lowest in sample roasted at $160^{\circ} \mathrm{C}$ for $60 \mathrm{~min}(0.02)$. Total saturated fatty acid (SFA) was highest in sample roasted at $100^{\circ} \mathrm{C}$ for $60 \mathrm{~min}(20.35 \%)$. The fatty acid composition can be an indicator of the stability and degradation rates of cashew nut and is also very important in terms of the nutritional value. Fatty acids composition of nuts is beneficial because SFA is low and MUFA content is significantly higher than SFA. Results of gas chromatography (GC-FID) analysis of the ethyl esters of saturated and unsaturated fatty acid of raw and roasted cashew nut showed that unsaturated fatty acids represented $60.57 \%$ for unroasted samples while roasted samples was between $79.67-83.67 \%$ while saturated fatty acids recorded lower value which ranged between $16.11-37.65 \%$. The fatty 
acid composition of the oils shows the presence of four main fatty acids: Palmitic C16:0 (9.25-29.50\%); stearic C:18:0 (4.4-9.34\%); Oleic, C18:1 (34.75-65.60\%); and linoleic, C18:2(1.35-20.66\%). Oleic $>$ linoleic $>$ palmitic $>$ stearic in all the samples irrespective of roasting conditions. It was observed that the roasting process did not significantly alter the profile of the fatty acids, especially the unsaturated fatty acids (C18:1, C18:2 and $\mathrm{C} 18: 3$ ). The oleic acid (monounsaturated) confers greater resistance to degradation or thermal action in edible oils. The oleic acid (monounsaturated) confers greater resistance to degradation or thermal action in edible oils. In addition, free fatty acids oxidize at a higher speed than its esters; therefore, they are considered as pro-oxidants.

Table 2. Saturated fatty acid composition of raw and roasted cashew kernel

\begin{tabular}{|c|c|c|c|c|c|c|c|}
\hline $\begin{array}{l}\text { Temperature } \\
{ }^{0} \mathrm{C}\end{array}$ & $\begin{array}{l}\text { Time } \\
(\mathrm{min})\end{array}$ & $\begin{array}{c}\text { Myristic } \\
\text { C14:0 }\end{array}$ & $\begin{array}{c}\text { Palmitic } \\
\text { C16:0 }\end{array}$ & $\begin{array}{l}\text { Stearic } \\
\text { C18:0 }\end{array}$ & $\begin{array}{c}\text { Arachidic } \\
\text { C20:0 }\end{array}$ & $\begin{array}{c}\text { Behenic } \\
\text { C22:0 }\end{array}$ & $\begin{array}{c}\text { Lignoceric } \\
\text { C24:0 }\end{array}$ \\
\hline Control & 0 & 1.15 & 29.50 & 4.44 & 2.04 & 0.52 & - \\
\hline \multirow[t]{3}{*}{100} & 20 & 0.15 & 8.89 & 7.52 & 0.45 & 0.05 & 0.01 \\
\hline & 40 & 0.05 & 9.25 & 8.30 & 0.10 & 0.03 & 0.05 \\
\hline & 60 & 0.03 & 10.71 & 9.34 & 0.23 & 0.04 & 0.03 \\
\hline \multirow[t]{3}{*}{120} & 20 & 0.04 & 9.87 & 9.24 & 0.09 & 0.03 & 0.04 \\
\hline & 40 & 0.11 & 8.84 & 7.61 & 0.30 & 0.03 & 0.01 \\
\hline & 60 & 0.05 & 9.66 & 8.16 & 0.28 & 0.03 & 0.05 \\
\hline \multirow[t]{3}{*}{140} & 20 & 0.06 & 8.33 & 7.35 & 0.33 & 0.03 & 0.06 \\
\hline & 40 & 0.04 & 9.09 & 8.10 & 0.36 & 0.02 & 0.04 \\
\hline & 60 & 0.06 & 10.39 & 9.42 & 0.25 & 0.03 & 0.06 \\
\hline \multirow[t]{3}{*}{160} & 20 & 0.07 & 8.59 & 7.25 & 0.39 & 0.04 & 0.07 \\
\hline & 40 & 0.04 & 8.94 & 8.85 & 0.22 & 0.03 & 0.04 \\
\hline & 60 & 0.04 & 10.59 & 9.28 & 0.33 & 0.02 & 0.04 \\
\hline
\end{tabular}

Table 3. Unsaturated fatty acid composition of raw and roasted cashew kernel

\begin{tabular}{|c|c|c|c|c|c|c|c|}
\hline $\begin{array}{l}\text { Temperature } \\
{ }^{0} \mathrm{C}\end{array}$ & $\begin{array}{l}\text { Time } \\
(\min )\end{array}$ & $\begin{array}{l}\text { Palmitoleic } \\
\text { C16:1 }\end{array}$ & $\begin{array}{l}\text { Oleic } \\
\text { C18:1 }\end{array}$ & $\begin{array}{c}\text { Linoleic } \\
\text { C18:2 }\end{array}$ & $\begin{array}{c}\text { Linolenic } \\
\text { C18:3 }\end{array}$ & $\begin{array}{l}\text { Arachidonic } \\
\text { C20:4 }\end{array}$ & $\begin{array}{l}\text { Erucic } \\
\text { C22:1 }\end{array}$ \\
\hline Control & 0 & 1.43 & 34.75 & 1.35 & 22.57 & 0.45 & -- \\
\hline \multirow[t]{3}{*}{100} & 20 & 0.27 & 64.70 & 17.54 & 0.38 & 0.05 & 0.02 \\
\hline & 40 & 0.15 & 62.58 & 19.31 & 0.13 & 0.04 & 0.01 \\
\hline & 60 & 0.09 & 59.58 & 19.85 & 0.09 & 0.02 & 0.01 \\
\hline \multirow[t]{3}{*}{120} & 20 & 0.14 & 59.74 & 20.66 & 0.13 & 0.03 & 0.01 \\
\hline & 40 & 0.19 & 64.73 & 17.87 & 0.28 & 0.04 & 0.01 \\
\hline & 60 & 0.17 & 62.00 & 19.39 & 0.15 & 0.04 & 0.01 \\
\hline \multirow[t]{3}{*}{140} & 20 & 0.19 & 65.60 & 17.82 & 0.16 & 0.05 & 0.01 \\
\hline & 40 & 0.13 & 62.63 & 19.41 & 0.12 & 0.03 & 0.01 \\
\hline & 60 & 0.18 & 59.28 & 20.12 & 0.16 & 0.05 & 0.01 \\
\hline \multirow[t]{3}{*}{160} & 20 & 0.21 & 65.51 & 17.63 & 0.19 & 0.06 & 0.02 \\
\hline & 40 & 0.14 & 62.46 & 19.11 & 0.13 & 0.04 & 0.01 \\
\hline & 60 & 0.12 & 59.52 & 20.40 & 0.11 & 0.03 & 0.01 \\
\hline
\end{tabular}


Table 4. Total saturated and unsaturated fatty acid contents of raw and roasted cashew kernel

\begin{tabular}{ccccccccccc}
\hline $\begin{array}{c}\text { Temp } \\
\left({ }^{\circ} \mathrm{C}\right)\end{array}$ & $\begin{array}{c}\text { Time } \\
(\mathrm{min})\end{array}$ & TSF & TMUFA & PUFA & TUS & TSF/TUS & O/L & Cox & OV & $\begin{array}{c}\text { Flavor } \\
\text { score }\end{array}$ \\
\hline Control & 0 & 37.65 & 36.18 & 24.39 & 60.57 & 0.62 & 25.74 & 5.36 & 6.65 & 5.37 \\
100 & 20 & 17.05 & 64.99 & 17.98 & 82.95 & 0.21 & 3.6 & 2.54 & 11.46 & 3.69 \\
& 40 & 17.13 & 62.74 & 19.53 & 82.27 & 0.22 & 3.2 & 2.64 & 12.98 & 3.16 \\
& 60 & 20.33 & 59.68 & 19.99 & 79.67 & 0.25 & 3.0 & 2.66 & 14.18 & 2.74 \\
120 & 20 & 19.26 & 59.58 & 20.86 & 80.74 & 0.24 & 2.89 & 2.75 & 12.83 & 3.21 \\
& 40 & 16.88 & 64.73 & 18.20 & 83.11 & 0.20 & 3.64 & 2.86 & 13.51 & 27.9 \\
& 60 & 18.17 & 62.18 & 19.63 & 81.83 & 0.22 & 3.20 & 2.65 & 14.52 & 2.62 \\
140 & 20 & 16.11 & 65.80 & 18.09 & 83.89 & 0.19 & 3.68 & 2.53 & 14.28 & 2.70 \\
& 40 & 17.62 & 62.77 & 19.60 & 82.38 & 0.21 & 3.23 & 2.65 & 15.13 & 2.41 \\
& 60 & 20.14 & 59.47 & 20.39 & 79.86 & 0.25 & 2.95 & 2.70 & 17.53 & 1.57 \\
& 20 & 16.37 & 65.74 & 17.95 & 83.67 & 0.20 & 3.72 & 2.71 & 12.24 & 3.42 \\
& 40 & 18.08 & 62.61 & 19.32 & 81.92 & 0.22 & 3.27 & 2.62 & 13.70 & 2.92 \\
& 60 & 20.25 & 59.65 & 20.64 & 80.27 & 0.25 & 2.91 & 2.73 & 15.11 & 2.41 \\
\hline
\end{tabular}

$T S F=$ Total saturated fatty acid; TMUFA=Total monounsaturated fatty acid; $O / L=$ Ratio of oleic to linoleic;

PUFA = Polyunsaturated fatty acid; TUS= Total unsaturated fatty acid; OV=oxidation value,

Cox $=$ Calculated oxidizability value

However, when they are present in small quantities, does not significantly act on oxidative stability Palmitic acid is a saturated fatty acid which does not raise blood cholesterol level when it is esterified in the alpha-position on the triglycerides as in palm oil. It is more hypercholesterolemia, when it is esterified in the beta-position as in butter fat according to $\mathrm{Ng}, 1994$. The data showed that roasting had an increment in unsaturated fatty acids and recorded the lowest value of saturated fatty acids. Saturated fatty acid form straight chain and as a result can be packed together very tightly, allowing organism to store chemical energy very densely (Patsch et al., 2000). Saturated fat is found to increase cholesterol production by the body. It also decreases insulin sensitivity, which cause body to store food more often as fat rather than other uses. Cashew nuts have high concentration of monounsaturated (MUFA) (36.18-65.80\%) and polyunsaturated (PUFA) fatty acids. The high levels of unsaturated fatty acid in this oil were due to their high level of oleic acid and linoleic acid. Linoleic acid is the most important essential fatty acid, for it must be obtained from food. This is because during the synthesis of unsaturated fatty acids, oleic acid can easily be formed from stearic acid. That is, the desaturation of stearyl-CoA to form oleyl-CoA occurs readily in the mammalian liver. On the other hand, the desaturation of oleyl-CoA which is supposed to form octadecadienoic acid (linoleic acid) is not possible. However, the desaturation of linoleic acid is possible with the formation of 2 products alpha-linolenic acid (in plants) and gammalinolenic acid(in animals). Gamma-linolenic acid, though found only in very small quantity in animal fats is an intermediate in the formation of arachidonic acid (Ottaway and Apps, 1984). Linoleic acid is therefore an essential component of the diet. An adult needs $10 \mathrm{~g} /$ day. These cashew nuts are therefore good sources of linoleic acid. Our values were also similar to those of peanut and palm olein oil where oleic acid is the most abundant and palm and coconut oils. According to Vemkatachalam and Sathe (2006), stearic acid comprises $9-10 \%$ of cashew nut oil, while its content in the present study was found to be between 7-9.5\% but differs from that of Kotaminas and Mexis, 2009 where the stearic acid was $18 \%$. Also, the total amount of MUFA according to Bender (2006) was $62 \%$ while the total amount of MUFA determined in the present study was $65 \%$ but differ from the result of Kotaminas and Mexis (2006) who obtained $50 \%$. Furthermore, lignoceric acid was a part of the lipid fraction of cashew nuts which is similar to the result obtained by Kotaminas and Mexis, 2009 who reported that lignoceric acid was obtained for the first time as part of the lipid fraction of cashew nut. This similarity may be due to similarity in cashew nut cultivar or maturity stage at harvest. The unsaturated fatty acid content $(83 \%)$ favours lipid oxidation. The recommended ratio of $n-6$ to $n-3$ fatty acid is estimated to be from 3 to 5 (Schaefer, 2002). The values obtained for this study falls within the range, hence all the samples were suitable for being used as good edible oil directly and their oil can be used as a good source of linoleic acid. Regarding the saturated fatty acids, stearic acid increased percentage wise $(p<0.05)$ especially at high temperature and time of roasting while oleic acid decreased percentage wise $(\mathrm{p}<0.05)$. This results is similar with the work of Kontominas and Mexis, 2009 who reported that stearic also increased at $\mathrm{p}<0.05$ at high irradiation doses of cashew nut while oleic acid decreased also. Linoleic and linolenic acids are essential fatty acids (EFA) that cannot be produced in the body but are essential for growth. Linoleic acid (a polyunsaturated fatty acid) moderately reduces serum cholesterol and LDL levels (FAO, 1994). Oleic acid is also reported to be useful in building cellular membranes, attracting oxygen to tissues, to transform energy into nerve impulses, and as precursors to molecules of cellular communication, such as prostaglandins or eicosanoids. Odutuga et al, (1992) demonstrated that the absence of these essential fatty acids could lead to scaly skin, necrosis and stunted growth. The deficiency of essential fatty acids has been linked to high blood cholesterol level and cholesterol has been shown to be a major constituent of the plagues that form on the inside of some blood vessels. All other fatty acids were not significantly affected by roasting temperature and time conditions. Given the very low moisture content of cashew nut and the relatively high temperature of roasting applied, it is most that free fatty acids were produced through triglycerides hydrolysis. Based on hydroperoxides data, it is clear that roasting caused partial decomposition of small number of triglycerides. For this reasons, MUFA were preferentially attacked by oxygen to produce primary and secondary oxidation product as opposed to attack of PUFA. Given the relative decrease in MUFA upon roasting and the observation that PUFA were not affected by roasting, the relative percentage of SFA increased. This SFA also remained unaffected significantly by roasting. According to the literature, heating of high moisture content foods results in high hydroxyl radical concentration which triggers fat oxidation leading to changes in fatty acid composition of fatty foodstuffs. Such reactions are expected to be slower in dry foodstuffs such as nuts (Sant Ana and Manani-fillni, 2000). Also, SFA 
such as C12:0, C14:0 and to a lesser C16:0 elevate serum cholesterol and LDL levels (FAO, 1994). Auld et al., (1992) stated that a reduced level of polyunsaturated especially linolenic acid and an increased content of monounsaturated fatty acid (Oleic acid) .provided higher oil stability and the resulting product can be used for food application requiring high cooking and frying temperature. Additionally, the nutritional quality of cashew nut oil can still be improved by increasing the dietary essential linoleic acid content and decreasing the $\alpha$-linolenic acid content (BeareRoger.1988).

\section{Conclusion}

The study showed that cashew nut oil contain high oleic to linoleic ratio which is associated with high oil stability hence the potential of the oil being use for deep fat frying as the oil is stable and non-drying due to their low iodine values and may not be suitable for soap making because of low saponification value. The roasting process did not significantly alter the fatty acid composition in cashew nuts. The oil can be used in pharmaceutical industries and for edible purposes such as production of conjugated linoleic acid and food emulsifiers. Cashew nut oil contains linoleic and linolenic acid which are essential for growth, physiological function and body maintenance as it lowers serum cholesterol. It can be used as an easily accessible source of natural antioxidant and a possible food supplement or in pharmaceutical industry. The fatty acid content together with total mineral (vitamin E) and phenolic contents could be taken into consideration by cashew breeders as selection criteria for developing genotypes with modified seed quality trait in Anacardium occidentale.

\section{Acknowledgement}

The author appreciates the support received from the technical assistants from Mr. Adenekan of the Department of Biochemistry, University of Lagos, Idi-Araba, Nigeria.

Conflicts of Interest: The authors have declared no conflict of interest for this article.

\section{References}

Abayomi, P., Isaac, A., Ayodele, O. (2002) Effect of processing conditions and packaging materials on the quality attributes of dry roasted peanut. Journal of Food Science and Agriculture, 82 1465-1471.

Adegoke, G.O., Falade, K.O., Babalola, O.C. (2004) Control of lipid oxidation and fungal spoilage of roasted peanut (Arachis hypogaea) using the spice of A. danielli. Food Agriculture and Environment 2(1) 128 - 131.

Ajav E.A. (1996) The design and testing of a low cost cashew-nut cracker for peasant farmers. Tropical Agriculture, 73 (3) $180-186$.

Akinoso, R., Igbeka, J., Olayanju, T. (2006) Process optimization of oil expression from sesame seed (Sesame indicum Lin). Agriculture Engineering International, The CIGR Ejournal, Manuscript ER 06011 VIII.

Akinwale T.O. (1996a) Cashew utilization: CRIN Experience. Proc. National Workshop 'Cashew Production Technology', March 26-29, Cocoa Research Institute of Nigeria (CRIN), Ibadan, Nigeria.

Akinwale, S.A., Esan, E.B. (1989) Advances in cashew breeding in Nigeria. In: Progress in Tree Crop Research, $2^{\text {nd }}$ Edn. Cocoa Research Institute of Nigeria(CRIN), Ibadan, Nigeria, pp:166-174.

A.O.A.C. (2005) Association of Official Analytical Chemists, $19^{\text {th }}$ ed. Official Methods of Analysis, Washington, D.C, U.S.A.

AOCS (2003) Official Method Cd 8-53. American Oil Chemists Society, Champaign, IL. Accessed on www.bioriginal.com.

Aremu, M.O., Olonisakin, A., Bako, D.A, P.C. Madu, (2006a) Compositional studies and physicochemical characteristics of cashew nut (Anacardium occidentale) flour. Pakistan Journal of Nutrition, 5 328-333.

Auld, D.L., Heikkinen, M.K., Erickson, D.A., Serny, J.L., Romero,J.E. (1992) Rapeseed mutants with reduced levels of polyunsaturated fatty acids and increased levels of oleic acid. Crop Science, $32657-662$.

Abou-Gharbia, H.A., Shehata, A.A.Y., Shahidi, F (2000) Effect of processing oxidative stability and lipid classes of sesame oil. Food Research International, 33 (30) 331-340.

Atul Mohod, Sudhir Jain A.G., Powar (2010) Pollution Sources and Standards of Cashew Nut Processing, American Journal of Environmental Sciences, 6 (4) 324-328.

Ayodele, E.A., Adebola, P.O., Aliyu, O.M., Olubamiwa, O. (2001) Research aspect of the cashew industry in Nigeria, Paper presented at $1^{\text {st }}$ Annual Conference of National Cashew Association of Nigeria (CAN), October, pp. 19.

Azam-Ali, S.H,. Judge, E.C (2001) Small-scale Cashew nut processing, ITDG Schumacher Centre for Technology and Development, Bourton on Dunsmore, Rugby, Warwickshire, UK.

Caribbean Technological Consultancy Services (CTCS) Network, (1993) Information package on cultivation, processing and marketing of cashews. St Michael, Barbados, Caribbean Technological Consultancy Services Network.

CEPC, (1992) Cashew week, Cochin India,1 (14) 3.

Codex Alimentarius (1999) Fatty acid composition of vegetable oils as determined by gas liquid chromatography from authentic samples. Codex STAN, pp. 210-1999.

Coenen, J.W.E. (1976) Hydrogenation of Edible Oil. Journal of the American Oil Chemists 'Society, 53 (6).

Chiou, R.Y.Y., Chang, Y.S.,Tsai, T.T. (1991a) Variation of flavour related Characteristics of peanut proteins during roasting as affected by initial moisture content. Journal of Agricultural and Food Chemistry, 391155 - 1158.

Cheftel, J.C., Cheftel, H. (1992) Introduction a la Biochimie et a la Technologie des Aliments. Technique et documentation, pp: 243 - 330 Paris Cedex. Champe, P.C., Harvey, R.A. (1994) Biochemistry. $2^{\text {nd }}$ Edition, Jenson Books Inc. Lippincott-Raven Publishers pp. 420.

Davis, K. (1999) Cashew, Echo Technical Note, June 14, 2001.

Demir A.D., Cronin K. (2004) The thermal kinetics of texture change and the analysis of texture variability for raw and roasted hazelnuts. International Journal of Food Science and Technology, 39 371-383.

Djeumako, B., Kapseu, C., Fomethe, A., Kamga, R. (2000) Extraction du Beurre de Karite par presse Manuelle: Contraintes. 3rd International Workshop on the improvement of Safou and other non-conventional oil crops. Yaoundé, Cameroon. 382-389. 
Djarwanto, A.S., Abdurrohim S. (2000) Wood preservation technology to lengthen its service life. Buletin Penelitian danPengembangan Kehutanan. Indonesia, 1 (2) 159-172. Overseas Development Natural Resources Institute Press, Chatham, Kent, UK.

Elmastry, G., Motto, E., Blasco, J., Elsyed, A. (2006) Effect of hot water treatment on some chemical and mechanical properties of potato, Agriculture Engineering International, The CIGR Ejournal, Manuscript. FR 05013, VIII.

Fatemi, S.H., Hammond, E.G. (1980) Analysis of oleate, linoleate and linolenate hydroperoxides in oxidized ester mixtures. Lipids, 15 (5) $379-385$. FAO (1994) Experts' recommendations of Fats and oils in human nutrition. Fats and oils in human nutrition: Report of a joint Expert Consultation, FAO Food and Nutrition Paper, 57 (7).

Holland, B., Welch A.A., Unwin I.D., Buss D.H., Paul A.A., Southgate D.A.T. (1991) The Composition of Foods. The Royal Society of Chemistry and Ministry of Agriculture, Fisheries and Foods. Xerox Ventura Publishing, Cambridge.

Irtwange, S.V. (2006) Hot Water Treatment: A non chemical alternative in keeping quality during post harvest handling of citrus fruits. Agricultural Engineering International, The CIGR Ejournal. Invited.

ITDG (2000) Cashew nut processing technical brief. Rugby, United Kingdom, ITDG. Journal of Chemical Education, 61 348-358.

Iwe, M.O. (2003) Handbook of sensory methods and Analysis Publ. Rejoint Communication Services Ltd. Uwani, Enugu, Nigeria.

Jain, R.K., Sivala K. (1997) Development of a cashew nut Sheller. Journal of Food Engineering, 32 339-345.

Kapchie, N.V., Tchiégang, C., Mbofung, C.M., Kapseu, C. (2000) Variation dans les caractéristiques physicochimiques des fruits de l'aiélé (Canarium schweinfruthii E.) de différentes provenances du Cameroun. 3rd International Workshop on the improvement of Safou and other non-conventional oil crops. Yaoundé, Cameroon, 249-262.

Kirk, R.S., Sawyer, R. (1991) Pearson's composition and Analysis of Foods, $9^{\text {th }}$ Edition, Addison Wesley Longman Ltd., England. 9 - 29, $608-640$. Krishnamurthy, R.G. (1982) Cooking oils, salad oils and salad dressings. In: Bailey's Industrial Oils and Fat Products. Vol 2. 4th Edition, (D. SWERN ed), John Wiley and Sons Inc., pp. 603, New York, USA.

Kosoko, S.B., Sanni, L.O., Adebowale, A.A., Daramola, A.O., Oyelakin,M.O. (2009) Effect of period of steaming and drying temperature on chemical properties of cashew nut. African Journal of Food Science, 3 (6) 156-164.

Liaotrakoon, W., Namhong, T., Yu, C.H., Chen, H.H. (2016) Impact of roasting on the changes in composition and quality of cashew nut (Anacardium occidentale) oil. International Food Research Journal, 23 (3) 986-991.

Makeri, M.U., Bala,S Kassum, A.S. (2011) The effect of roasting temperatures on the rate of extraction and quality of locally-processed oil from two Nigerian peanut (Arachis hypogeal L) cultivars. African Journal of Food Science, 5 (4) 194-199.

Mabaleha, M.B., Yeboah, S.O. (2004) Characterization and compositional studies of the oils from some legume cultivars, Phaseolus vulgaris, grown in Sothern Africa. Journal of American Oil Chemists Society. 81 361-364.

Mexis, S.F., Kontominas, M.G. (2009) Effect of $\gamma$-irradiation on the physicochemical and sensory properties of cashew nuts (Anacardium occidentale L.). Food Science and Technology, 42 (9) 1501-1507.

Moreau, R.A., Hicks, A.A., Powel, M.J. (1999) Effect of heat pretreatment on the yield and composition of oil extracted from Corn fibre. Journal of Agriculture Food Chemistry, 47 2867-2871.

Muhammad, N., Bamishaiye, E., Bamishaiye, O., Usman L., Salawu M., Nafiu M., Oloyede, O. (2011) Physicochemical properties and fatty acid composition of cyperus esculentus (Tiger Nut) Tuber Oil. Biores. Bull. 5 51-54.

Ng, TKW, (1994) A critical Review of the Cholesterolaemic effects of palm Oil. Food and Nutrition Bulletin. 1513.

Nagabhushana K.S., Ravindranath, B. (1995) Efficient medium scale chromatographic group separation of anacardic acids from solvent extracted CNSL. Journal of Agricultural and Food Chemistry, 43 (9).

Niki, E., Yoshida, Y., Saito, Y., Noguchi, N. (2005) Lipid peroxidation: Mechanisms, inhibition, and biological effects. Biochemical and Biophysical Research, 333 668-676.

Ohler J.G. (1979) Cashew Growing: Tropical Abstracts. Cashew Dept. Agric. Res., Royal Tropical Institute Press, Amsterdam.

Olaofe O., Okiribiti B.Y., Aremu M.O. (2008) Chemical evaluation of the nutritive value of smooth luffa (Luffa cylindrical) seed's kernel. Electronic Journal of Environmental, Agricultural and Food Chemistry, 7 (10) 3444-3452.

Opeke, L.K. (2005) Tropical commodity. Tree crops. Spectrum Books, Ibadan. pp. 107 -109.

Ozdemir, M., Ackurt, F., Yildiz, M., Biringen, G., Gurcan, T., Loker, M. (2001a) Effect of roasting on some nutrients of hazelnuts (Corylus avellena L.). Food Chemistry, 73 185-190.

Ozdemir, M., (2001) Mathematical analysis of color changes and chemical parameters of roasted hazelnuts, Ph.D Thesis.

Rajko V., Sergeja V., Helena, A. (2010) Biochemical parameters and oxidative resistance to thermal treatment of refined and unrefined vegetable edible oils. Czech Journal of Food Sciences, 28 376-384.

Saklar., S. A., Ungan, S., Katnas, S. (2003) Microstructural changes in hazelnuts during roasting. Food Research International, 36 (1) 19-23.

Sant Ana, L.S., Mancini Filho, J. (2000) Influence of the addition of antioxidant in vivo on the fatty acid composition of fish fillet. Food Chemistry, $68175-178$.

Steel, R.G., Torie, J.A. (1980) Principle and Practice of statistics, $2^{\text {nd }}$ Edition, New York, MacGraw-Hill.

Tamzid, H. M., Alam, M.T., A-U-Islam, M. (2007) Physico-chemical and nutritional studies of terminalia belerica roxb. seeed oil and seed kernel. Journal of Bio-Science, 15 117-126.

Thivavarnvongs, T., Okamoto, T., Kitani, O. (1995) Development of compact sized cashew nut shelling machinery (Part 1). Synthesis of effective manual and semi-automatic shelling methods. Journal of the Japanese Society of Agricultural Machinery, 57 (2) 57-76.

Venkatachalam, M., Sathe, S. (2006) Chemical composition of selected edible nuts. Journal of Agricultural and Food Chemistry, 544705 - 4714. 